De Almeida, Eneida.

Profesora doctora, investigadora, Universidad São Judas Tadeu, Posgrado en arquitectura y urbanismo.

Nascimento, Myrna de Arruda.

Profesora doctora, investigadora, Universidad de São Paulo, Departamento de Proyecto FAUUSP.

\title{
Narrativas errantes entre espacios reales e imaginarios: obras, imágenes y los lugares de los discursos
}

\section{Wandering narratives between real and imaginary spaces: works, images and places of speeches}

TIPO DE TRABAJO: Comunicación.

\section{PALABRAS CLAVE}

Arte contemporánea, formas de reproducción, crítica y producción, performance.

KEY WORDS

Contemporary art, forms of reproduction, criticism and production, performance.

\section{RESUMEN}

Si el museo, al separar la obra de arte del mundo 'profano' inauguraba una nueva relación con el público, consagrando su condición autónoma, las recientes diversificaciones de las formas de reproducción - digitales o analógicas -, amplían infinitamente la posibilidad de confronto entre museos reales e imaginarios, como indica Malraux (1994), estimulando prácticas culturales en permanente elaboración y circulación.

Este trabajo explora la discusión provocada por la profusión de imágenes en el ambiente cultural contemporáneo, aproximando visiones polisémicas formuladas en narrativas provenientes de distintos lugares de discurso: el relato del escritor que lee imágenes e cuenta lo que ve se entrelaza con la comprensión de los críticos de arte y con el discurso del artista que usa la palabra y la escritura como instrumentos de reflexión y de dirección del propio proceso creativo.

Alberto Manguel (2000) establece un paralelo entre imágenes y palabras como medio de reconocimiento de la experiencia del mundo denominado "real".

George Kluber (2002) sobrepone el dominio de las cosas hechas por el hombre al de la historia del arte, investigando la producción artística en Europa occidental por medio de las relaciones establecidas entre "objetos primos" y réplicas, o sea, un complejo encadenamiento desarrollado en el transcurso del tiempo, entre entidades originales y sus derivaciones, réplicas, transposiciones.

Luigi Pareyson (2002) contrapone tal noción, substituyendo la idea de origen y derivación de la imagen por la concepción de un proceso endógeno resultante de motes y estímulos impulsados por el propio quehacer artístico, movido por la dinámica de alternancia entre consciencia y espontaneidad, entre sistema e libertad.

La producción contemporánea de Esther Ferrer, al lidiar con la regla y el acaso, transitando por diferentes lenguajes, reaproximando arte y vida, memoria e invención, permite un análisis empírico en el cual las diferentes comprensiones aquí referenciadas pueden ser discutidas y confrontadas. 


\section{ABSTRACT}

If the museum, by separating the work of art from the 'profane' world, inaugurated a new relationship with the public, consecrating its autonomous condition, the recent diversification of forms of reproduction - digital or analogical - infinitely expand the possibility of confrontation between museums real and imaginary, as Malraux (1994) indicates, stimulating cultural practices in constant elaboration and circulation.

This work explores the discussion provoked by the profusion of images in the contemporary cultural environment, approaching polysemic visions formulated in narratives from different places of discourse: the narrative of the writer who reads images and tells what he sees is intertwined with the understanding of critics of art and with the discourse of the artist who uses the word and writing as tools for reflection and direction of the creative process itself.

Alberto Manguel (2000) establishes a parallel between images and words as a means of recognizing the experience of the world called "real".

George Kluber (2002) superimposes the dominance of the things done by the man to the one of the history of the art, investigating the artistic production in Western Europe by means of the established relations between "primitive objects" and replicas, that is to say, a complex chain developed in the course of time, between original entities and their derivations, replicas, transpositions.

Luigi Pareyson (2002) contrasts this notion, replacing the idea of origin and derivation of the image by the conception of an endogenous process resulting from motes and stimuli driven by the artistic task itself, driven by the alternating dynamics between consciousness and spontaneity, between system and freedom.

The contemporary production of Esther Ferrer, dealing with rule and chance, transiting through different languages, re-approaching art and life, memory and invention, allows an empirical analysis in which the different understandings referenced here can be discussed and confronted.

\section{INTRODUCCIÓN}

Critical appraisals accompany works of art from immemorial time, however, this process of reflection that revolves around them does not replace them, nor does it enclose them in a single interpretative key.

This work explores the discussion provoked by the profusion of images in the contemporary cultural environment, approaching polysemic visions formulated in narratives coming from different places of discourse: the writer's account that reads images and tells what he sees intertwined with the understanding of art critics, and to the speech of the artist who makes use of the word and of writing as an instrument of reflection and of conducting the own inventive process. From Mangel we apprehend the memory of the situations that revolve around the images and the ideas conveyed by them, passing through Malraux and his museum of the imaginary; from Kluber we assimilate the web of relationships that are established between works or that can be recognized; inspired by Pareyson we abandon the idea of origin and derivation, to weave the approach with the process of creation of the artist, Esther Ferrer, and to enjoy the alternation between system and freedom.

\section{Images and words in connection}

Alberto Manguel, transiting off the fields of theory, criticism or history of art, establishes a parallel between images and words as a mean of recognizing the experience of the so-called "real" world. He declares that the same taste cultivated by the reading of words is also dedicated by him to the reading of images, interested in, above all, to unravel the stories intertwined with works of art and, for this reason, claims for common viewers the task and the right to read the pictures and translate them into words, to tell their stories. He associates this pleasure with the articulation between text and images a habit developed in his childhood, recalling the unforgettable experience in which, for the first time, he had in his hands a book whose images did not correspond, as he had hitherto known, to illustrations accompanying a narrative, but appeared isolated and challenging for a reading: they were paintings by Van Gogh, one in particular was etched in the writer's memory (Figure 1). 


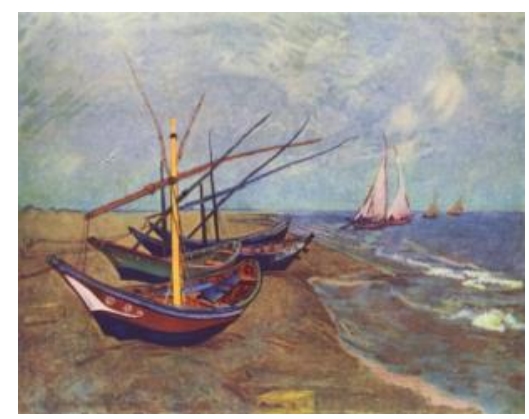

Figure 1. Boats on the beach of Saintes-Maries, Van Gogh. Retrieved 3 March, 2019 from https://commons.wikimedia.org/wiki/File:Vincent_Willem_van_Gogh_042.jpg

This memory, while favoring the connection between images and words, refers to the reflection of ancient Greek philosophers, for whom knowledge was associated with memory. Among them, Aristotle, the founder of peripatetic thought, mentions that every thought process called for the presence of images, these "like words, are matters of which we are made" (Manguel 2001: 21).

This inseparable condition between self-awareness and what is known, between thought, recollection, images, and personal identity, reports the writer to Bacon's proposition, which in the sixteenth century associated the understanding and interpretation of what we encounter with our own experience. This understanding certainly applies to reading images:

(...) we can only see what, in some form or form, we have already seen before. We can only see the things for which we already have identifiable images, just as we can read in a language whose syntax, grammar, and vocabulary we already know (MANGUEL, 2001, 27). ${ }^{1}$

Using this argument, Manguel admits that in the course of time we can better understand an image, lend it more precise words to tell what we see. This conduct would lead us to attribute to the images the character of narrative and, thus, give the works an infinite and inexhaustible life.

As he wanders through the relationship between words and images, Manguel appeals to André Malraux and his active participation in the political and cultural life of twentieth-century France, as someone who warned that:

(...) by situating a work of art among the works of art created before and after it, we, the modern spectators, became the first to hear what he called the 'song of metamorphosis' - that is, the dialogue that a painting or sculpture hangs with other paintings and sculptures, from other cultures and from other times (MANGUEL, 2001, pp. 27-28) ${ }^{2}$

In II museo dei musei it is possible to have direct contact with the discussion proposed by Malraux (1994), when observing that the photographic reproduction, at first corresponded to a modest means of diffusion of the works, with the purpose of allowing the masterpieces to be better known, confirming its invaluable value. However, the extensive diffusion of certain works ends up feeding their investigation through reproductions and, often, they replace the appreciation of the work itself. Similarly, when museums collect copies, they select them more freely, since they are not obliged to possess the originals copied, thereby adding to the rivalry of the original works, determined by confrontation, a contribution to the history of succession of copies (Figure 2).

\footnotetext{
${ }^{1}$ Translated by the authors

${ }^{2}$ Translated by the authors
} 


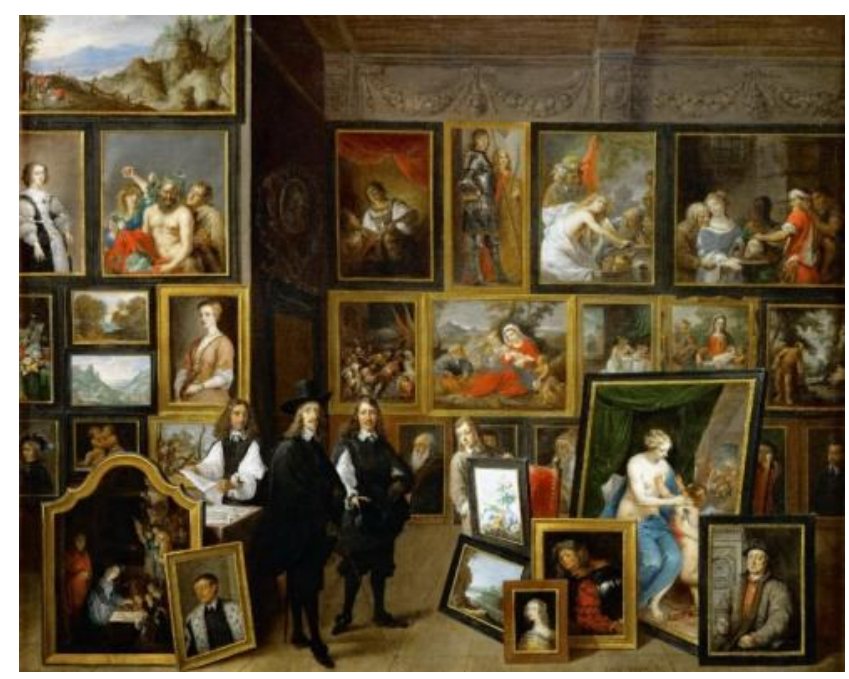

Figure 2. Archduke_Gallery Leopold in Brussels, David Teniers. Retrieved 3 March, 2019 from https://fr.wikipedia.org/wiki/Fichier:David Teniers II _Archduke_Leopold_Wilhelm_and_the_artist_in_the_archducal_picture_gallery_in_Brussels_(1653).jpg

\section{The (in) visible links between prime objects and replicas}

American historian and art critic George Kubler in La forma del tempo (2002) persits on tracing the clues in search of the relation between originals and copies, attentive to the modes of classification, description, periodization, and interpretation of art in Western Europe. In seeking to establish a new line of interpretation, he recognizes that, although Cassirer's definition of art as a symbolic language dominated the twentieth century, this understanding determined a disinterest in art as a system of formal relations.

Within this universe, two classes of objects deserve special attention: the cousins and the replicas; the work of art seen from two different angles: that of the public and that of artists.

By prime objects and replicas, we understand the main inventions with all that complex of duplicates, reproductions, copies, reductions transpositions and derivations that follow in the course of an important work of art. The grouping of replicas resembles certain habits of popular language, as a derivation of a phrase used by a theatre or cinema actor and which is repeated millions of times, until it becomes part of the language of a generation and finally a dated cliché (Kubler, 2002: 51) $)^{3}$

Always based on the idea of the prime object, the author considers it necessary to reorder the notions of integrity and unity of the work of art. He recognizes that some celebrated works are known by means of smaller replicas, thus admitting the importance of the replicas, since they allow to enlarge the knowledge of the prime object, which would be associated with "(...) a confused mass of replicas surrounded by uncertainties. "

At some point along the way, uncertainty involves the very existence of the prime object: "Do prime objects have a real existence? Or are we perhaps to give an extra symbolic distinction of imaginary prominence to some standard objects of a certain class? "(Kubler, 2002 , 54). Primal objects would correspond, according to the author, to initial traits or mutant intentions of a productive chain, while the replicas would be equivalent to variations of prime objects.

Kubler compares prime objects to prime numbers in their originality, inability to be decomposed and associated with antecedent phenomena. In this sense, the history of art would correspond to a chain composed of links interrupted in certain sections, or simply joined in a precarious way, in order to keep linked together a few pieces considered as "testimony of the invisible sequence of prime objects".

The American critic, in discussing the propagation of forms, takes up Focillon's contribution and his understanding that the reproductive forces resided in the things themselves, an intuition that Malraux later developed on a larger scale, as the critic points out. In a sense, Pareyson follows this same path in devising his theory of formativity.

\footnotetext{
${ }^{3}$ Translated by the authors.
} 


\section{The formation of the image between rule and freedom}

In The Problems of Aesthetics (1997), Luigi Pareyson, formulates his thoughts on art, claiming not to propose an aesthetic of contemplation, but rather of production, not an aesthetic of expression, but of "formativity." His research debates about the limits that form different fields of approach to artistic production. In a purely philosophical inquiry, this reflection is built on the aesthetic experience:

a reflection on art, or is philosophical, like aesthetics, and then re-enters philosophy, or is the work of critic, or historian, or theorizer of art, and then enters the aesthetic experience as the object of philosophy. Aesthetics is philosophy precisely because it is speculative reflection on the aesthetic experience, which contains all the experience that has to do with beauty and art: the experience of the artist, the reader, the critic, the historian, the art technician and of the one who enjoys any beauty (PAREYSON 1997: 5). ${ }^{4}$

The Italian philosopher presents the fundamental principles of his aesthetics of "formativity" by relying on the question of what distinguishes the production of the work of art from other human works and examining the three most recurrent definitions of art in the history of Western thought: art as an act of doing; as an acquaintance; as a way of expressing .

His course began in Antiquity, a period in which the conception of art as a manufacturing prevailed, similar to the work of craftsmanship.

With romanticism, the author affirms, the third understanding predominates, art as expression, which distances it from external canons of beauty, since it would be identified by the feeling that the artistic figures animate and arouse in the other. To say that 'art is an expression of feeling', according to Pareyson, can be valid in the field of poetics, but debatable, in the realm of aesthetics, since this understanding "does not exhaust the essence of art, since one dose nota understand which feeling an arabesque, or an abstract music, or an architectural work can express ... ". However, the author points out that this conception of art as an expression persisted based on the theories of Dewey and Croce, who conceive art as language, and flowed into semantic theories. He explains that the term "language" is used in a metaphorical sense and refers to the expression "(...) as a form, that is, an organism that lives on its own and contains everything it must contain. (...) The form is expressive while its being is a saying, and it does not have as much as, but is a meaning ". (PAREYSON, 1997, p.23).

Also recurring in the course of Western thought, notes Pareyson, is the second definition of art, as knowledge, vision and contemplation, taking to a secondary plane the peculiarities of its execution. Two positions are alternated here: sometimes art is considered as the supreme form of knowledge, sometimes as a tiny form, but always as a vision of reality: " (...) or of the sensible reality in its full evidence, or of a metaphysical reality superior and truer, or of a more intimate, profound and emblematic spiritual reality ${ }^{5}$ (PAREYSON, 1997: 22).

Art, continues Pareyson, is not itself knowledge, contemplation, it qualifies in a special way these functions and thus reveals "(...) a sense of things and causes a specific person to speak in a new and unexpected way, teaches a new way of looking and seeing reality" ; Thus, the contemplation of the artist remains in his work (PAREYSON, 1997, p.25).

After going through the most recurrent definitions of works of art and situating them in historical time, the author weaves his conception of art as "formativity". He emphasizes that the essential aspect of art is the productive one, but he warns that this "realizative" trait is not exclusive to art, referring also to the universe of technique and crafts.

But art is production and realization in an intensive and eminent, absolute sense, to such an extent that it was often called creation, whereas it is not only the production of organisms that, like those of nature, are autonomous, independent and live on its own, but also achieves the production of radically new objects, true and proper increase of reality, ontological innovation. The fact is that art is not only making, producing, performing, and the simple "doing" is not enough to define its essence. Art is also invention. It is not execution of anything already devised, realization of a project, production according to rules given or predisposed. It is such a do that while doing, invents the what to be doing and the way to do. (PAREYSON, 1997, pp. 25-26). 7

From this understanding comes his definition of the inseparable art of "doing", as a "form", which consists in executing, producing, but above all is "inventing", figuring, discovering. Thus, the concepts of form and formativity are recognized by the author as the most appropriate to qualify art and artistic activity, respectively. In this perspective, works of art are autonomous organisms endowed with internal legitimacy, which presupposes a dynamic conception of artistic beauty, no longer associated with an idea of origin and

\footnotetext{
${ }^{4}$ Translated by the authors.

${ }^{5}$ Translated by the authors.

${ }^{6}$ Translated by the authors.

${ }^{7}$ Translated by the authors.
} 
derivation of the image, but characterized by the conception of an endogenous process initiated by mottos and stimuli driven by the artistic work itself, and driven by the alternating dynamic between consciousness and spontaneity, between system and freedom

\section{Ferrer's production between repetition and unpredictability}

A presentation text of her work at the Reina Sofía Museum ${ }^{8}$ highlights the process of an incredibly critical production, which overflows "the limits of language and time, placing the body in the central place, where it simultaneously transforms it into subject and object." There is also evidence of alternation between repetition and chance as a resource capable of enhancing the many subtle variations between similarity and otherness, between predictability and unexpected connections. The selection, according to the curatorship, "includes performances and installations, as well as a series of plastic projects, both preparatory and finished series, and documentation of the main actions (photographs and videos)." It brings together an expressive set of her production, from the series of the Self-portraits in process since the 1980s, to the prime numbers (Figures 3, 4, 5 and 6).
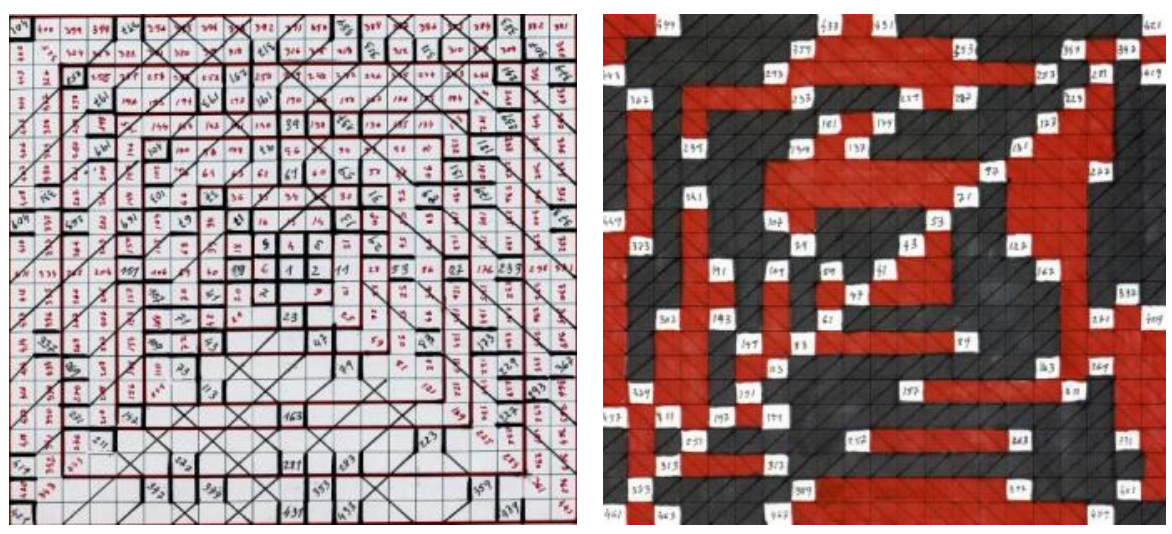

Figures 3 and 4. Extracted from the series "Prime numbers". Retrieved 3 March 2019, from

https://commons.wikimedia.org/wiki/File:Dibujo_sin_t\%C3\%ADtulo.jpg. https://commons.wikimedia.org/wiki/File:Dibujo_no_titulado.jpg

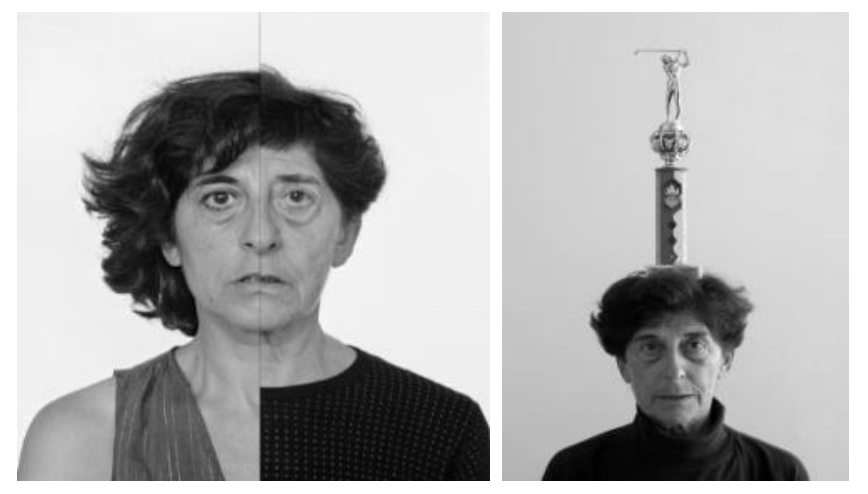

Figures 5 and 6. From the series Self-portrait. Retrieved 3 March 2019 from http://myartguides.com/people/ferreresther/attachment/1b488d67ff890604198cee9322f4f165-esther-agenda/

The writing by Esther Ferrer entitled Utopia and Performance, for the Seminar of the Institute of High Artistic Studies of Paris, dedicated to the theme "The shelter and the utopia" ${ }^{9}$, is a valuable material for an empirical approach, disposing side by side the work and the artist's report about the process production and the relevance of performance in her recent work. Ferrer begins her speech by analyzing the figure of the woman in the utopias, mentioning the symbolic (and utopian figure, in the artist's view), of the mother who, at the same time as celebrating her generative force, also closes in a cultural model ruled by logic patriarchal. Although the figure of the woman is not exactly the subject of the seminar, the artist introduces it based on the understanding of certain analysts that "the utopian phantasy can be (as is also the dream), a way of accessing the unconscious".

\footnotetext{
${ }^{8}$ Regarding an exhibition entitled "All variations are valid, including this", held between October 26, 2017 and February 25, 2018. Retrieved 20 February, 2019, from https://www.museoreinasofia.es/exposiciones/esther-ferrer>.

${ }^{9}$ Retrieved 14 January 2019, from <http://performancelogia.blogspot.com/2007/01/utopa-y-performance-esther-ferrer.html>
} 
Referring to the classic utopian narratives, practically all written by men, and the absence of women in charge of utopian society, speaks of themselves and their work. "Utopia is the place of total shelter, where it is protected against everything, the art of performance, on the other hand, is the art of non-shelter." ${ }^{10}$

She comments that the main characteristics of performance are the direct relationship between the public and the performer's "I", without mediation and in no circumstance of distancing, not even the physical distance, which gives it certain instability and unpredictability, since it is subject to the accident (Figures 5 and 6).

\begin{abstract}
En la performance, la cuestión no es que el público se identifique con el héroe de la acción, como ocurre generalmente en el teatro, o con el proyecto utópico, sino que se identifique con él mismo y actúe en consecuencia. Esto no significa que la performance - al menos tal y como yo la entiendo - pretenda y busque la participación del público, al menos yo nunca la he buscado. Simplemente hay dos presencias: la del performer y la de los otros, dos presencias individualizadas y como tales, cada cual tiene la libertad de actuar como le parezca mejor. (FERRER, 2007)
\end{abstract}

\title{
CONCLUSIONS
}

To the writer's apprehension, to the critic's examination, and to the philosopher's reflection, superimpose the narrative of the artist Esther Ferrer, which not only exposes her own work process, but translates it as a critical confrontation, a melee with what we identify as the real world.

Thus, a way of producing art that allows the integration between artist and the object of art is configured. Faced with the unidirectional and stable condition of utopia, one emphasizes the mutability of performance, such as the affirmation of an open work.

Uncoiling this kind of narrative spiral, which relates different places of discourse to an empirical approach, has made possible not only the confrontation but also the reconciliation between the field of theoretical reflection and the territory of practical experimentation.

\section{REFERENCE SOURCES}

Ferrer, E. (2007). Utopía y performance. In Seminar del Instituto de Altos Estudios Artísticos de Paris "L'abri et l'utopie" Retrived 14 jan. 2019 from http://performancelogia.blogspot.com/2007/01/utopa-y-performance-esther-ferrer.html.

Kubler, G. (1972). La forma del tempo. La Storia dell'arte e la Storia delle cose. 2002. Traduction by Giuseppe Casatellode.Torino: Einaudi.

Manguel, A. (2000). Lendo imagens. São Paulo: Companhia das Letras.

Malraux, A.(1951). II museo dei musei. 1994.Traduction by Liliana Magrini. Milano: Leonardo.

Pareyson, L. (2002). Estetica. Teoria della formatività. Firenze: Bompiani.

Pareyson, L. (1996). Os problemas da estética. 1997. Traduction by Maria Helena Nery Garcez. São Paulo: Martins Fontes.

\footnotetext{
${ }^{10}$ Translated by the authors
} 